\title{
RISK-BASED APPROACH IN THE EUROPEAN UNION LEGISLATION TO PREVENT MONEY LAUNDERING AND FINANCING OF TERRORISM
}

\author{
Victoria COCIUG ${ }^{1}$, PhD in Economics, Associate Professor, \\ Academy of Economic Studies of Moldova \\ Teodor ANDRUSCEAC ${ }^{2}$, PhD Student, \\ Academy of Economic Studies of Moldova
}

DOI: https://doi.org/10.36004/nier.es.2020.1-04

JEL Classification: E42, G23, G28, G32, K42

UDC: 339.19(4-672) UE

\section{ABSTRACT}

Money laundering and terrorism financing are serious and internationally emerging issues that must be approached and confronted at European Union level. The latest terrorist attacks and periodic banking scandals highlight the necessity for additional attention in this particular direction. In regard to the internal EU market, financial flows are integrated and trans-border by nature, thus funds can circulate rapidly, from one country to another, offering the possibility to perpetrators and terrorists to transfer money across Member State avoiding detection by authorities. This specific situation generates the necessity to identify and understand the particular ML/TF risks generated by services and products offered within the EU economic and financial ecosystem. In order to ensure an efficient mechanism for identifying the $M L / T F$ risks associated with the products and services provided on the territory of European Union, the 4AMLD provides the obligation of the EU Commission to perform once in two years the so-called European Union Money Laundering and Terrorist Financing Supranational Risk Assessment. Since 2017 two supra-national risk assessments were carried out and the final results are used by Member States to monitor the evolution of risks at Union level and to implement the necessary recommendation for ensuring a proper minimization of threats and vulnerabilities at the national level. This paper aims to analyze, understand and compare the main outcomes of the two assessments, namely the identified risks and their links with vulnerable sectors, as well as the evolution or devolution of certain risks as a result of mitigation measures applied by EU Member States. Another task of this article is to provide additional recommendations in terms of mitigating measures and efforts, which must be taken into account by Member States.

Keywords: risks, money laundering, financial services, threats and vulnerabilities, customer due diligence, beneficial owner.

Spălarea de bani și finanţarea terorismului sunt probleme serioase, care apar la nivel internațional, dar care trebuie abordate și confruntate inclusiv la nivelul Uniunii Europene. Ultimele atacuri teroriste și scandaluri bancare periodice evidențiază necesitatea unei atenții suplimentare în această direcție. In ceea ce privește piața internă a UE, fluxurile financiare sunt integrate și transfrontaliere, prin urmare, fondurile pot circula rapid, dintr-o țară în alta, oferind posibilitatea autorilor și teroriștilor de a transfera bani în statele membre, evitând detectarea de către autorități. Această situație specifică generează necesitatea identificării și înțelegerii riscurilor specifice $M L / T F$ generate de serviciile și produsele oferite în cadrul ecosistemului financiar și economic al UE. Pentru a asigura un mecanism eficient pentru identificarea riscurilor de ML/TF asociate cu produsele și serviciile furnizate pe teritoriul Uniunii Europene, $4 A M L D$ prevede obligația Comisiei UE de a efectua o dată în doi ani evaluările riscurilor supranaționale pentru spălare și finanțare a terorismului în conformitate cu criteriile UE. Din 2017 au fost efectuate două evaluări de risc supra-național, iar rezultatele finale sunt utilizate de statele membre pentru a monitoriza evoluţia riscurilor la nivelul Uniunii și pentru a

\footnotetext{
1 Victoria COCIUG, $\bowtie v_{-}$cociug@mail.ru

${ }^{2}$ Teodor ANDRUSCEAC, $\bowtie$ andrusceac@gmail.com
} 
implementa recomandarea necesară pentru a asigura o minimizare adecvată a amenințărilor și a vulnerabilităților la nivel național. Acest articol își propune să analizeze, să înțeleagă și să compare principalele rezultate ale celor două evaluări, respectiv riscurile identificate și legăturile acestora cu sectoarele vulnerabile, precum și evoluția sau devoluția anumitor riscuri ca urmare a măsurilor de atenuare aplicate de statele membre ale UE. $O$ altă sarcină a acestui articol este de a oferi recomandări suplimentare în ceea ce privește măsurile și eforturile de atenuare, care trebuie să fie luate în considerare de către statele membre.

Cuvinte-cheie: riscuri, spălare a banilor, servicii financiare, amenințări și vulnerabilități de spălare a banilor, cunoaşterea clientului, beneficiarul final.

Отмывание денег и финансирование терроризма - это серьезные и возникающие на международном уровне проблемы, которые необходимо выявлять и решать на уровне Европейского Союза. Последние террористические акты и периодические банковские скандалы подчеркивают необходимость дополнительного внимания в этом конкретном направлении. Что касается внутреннего рынка EC, финансовые потоки являются интегрированными и трансграничными по своей природе, таким образом, финансовые потоки могут быстро циркулировать из одной страны в другую, предоставляя возможность преступникам и террористам переводить деньги через государство-член, избегая обнаружения властями. Эта конкретная ситуация порождает необходимость выявления и понимания конкретных рисков ОД/ФТ, создаваемых услугами и продуктами, предлагаемыми в рамках экономической и финансовой экосистемы ЕС. Для обеспечения эффективного механизма выявления рисков ОД/ФТ, связанных с продуктами и услугами, предоставляемыми на территории Европейского Союза, 4AMLD предусматривает обязательство Комиссии ЕС раз в два года выполнять оценку наднационального риска отмывания денег и финансирования терроризма согласно установленным критериям. С 2017 года были проведены две наднациональные оценки рисков, и окончательные результаты используются государствами-членами для мониторинга эволюции рисков на уровне Союза и выполнения необходимых рекомендаций для обеспечения надлежащей минимизации угроз и уязвимостей на национальном уровне. Цель этой статьи проанализировать, понять и сравнить основные результаты двух оценок, а именно выявленные риски и их связи с уязвимыми секторами, а также эволюцию или передачу определенных рисков в результате мер по смягчению, применяемых государствами-членами EC. Другая задача этой статьи состоит в том, чтобы предоставить дополнительные рекомендации в отношении смягчающих мер и усилий, которые должны быть приняты во внимание государствами-членами.

Ключевые слова: риски, отмывание денег, финансовые услуги, угрозы и уязвимость к отмыванию денег, надлежащая проверка клиентов, конечный бенефициар.

\section{INTRODUCTION}

The money laundering is a significant concern and a growing problem for European Union because of its enormous internal market and numerous services and products, which can be used by criminals to legalize illicit proceeds obtained from various illegal activities such as corruption, tax evasion, fraud, smuggling, etc. The European Union is an important trade player with a considerable share in the worldwide trade, which means that EURO is used by many participants and members of internal and external commercial and economic exchange, thus the European Union is an important target for those who want to hide the origin of their dirty money and to use the rights and freedoms of the EU common market for this purpose. In addition, the money laundering risk is highlighted by the fact that its Member States are using different legal and financial systems, which can be used by offenders to launder criminal funds or assets. Thereby, the issue of identifying and assessing money laundering risks at the EU level was and still is a major concern, in this regard the mechanisms for fighting with this phenomenon being updated and adapted. It is to mentioned that the first reference to the question of the weak transaction reporting and the problem of money laundering by drug traffickers could be traced to European Parliament Resolution of October 1986 [9]. Soon after, during the meetings of the Ministers, the Council proposed the Member States to consider mutual 
recognition, as well as enhanced cooperation on freezing and confiscation of the drug traffickers' assets [8]. Next year, the European Community was engaged in the preliminary work on the United Nations Vienna Convention, which, among other things, covered the criminalisation of money laundering derived from drug-related offences [4], even if the term of money laundering is not directly mentioned in the document.

Today, the money laundering risk is seen as a menace for Union's security, financial integrity and stability, as well as a tool for encouraging the individual perpetrators, organized crime and terrorists to transfer their grey assets into the legal economy. In order to facilitate the fight against money laundering, as well as of terrorism financing and to strengthen the established AML/CFT ecosystem at the level of European Union and Member States, the European Parliament and Council approved on 20.05.2018 the Directive No. 2015/849 on the prevention of the use of the financial system for the purposes of money laundering or terrorist financing. This specific document aims to enhance the Union's existent regime and introduces a new instrument tailored for assessing the money laundering and terrorist financing risk at the level of the European Union. This instrument known as the supranational risk assessment (SNRA) has the role to identify and evaluate the exposure of various sectors, products and services to the money laundering and terrorist financing risks and to propose a list of mitigating measures that can be used to harmonize and synchronize the general effort of Member States in addressing the above-mentioned risks. It is clear that the problems related with money laundering can be effectively approached by Member States only through introducing concrete legal and institutional barriers specifically adapted to each AML/CFT regime in part. However, there are several common shortcomings identified during the SNRA that can be used by Member States as a starting point for improving their local AML/CFT system. The purpose of this paper is to analyse the results of the existent SNRAs and to propose additional recommendations for minimizing the effect of money laundering phenomena in Member States and as a consequence to strengthen the European Union AML/CFT regime. The present article can be treated and viewed as a scientific opinion concerning the findings and outcomes of SNRAs.

\section{LITERATURE REVIEW}

The history of important global regulations related to AML can be traced since 1988, together with the entry into force of the United Nations Convention Against Illicit Traffic in Narcotic Drugs and Psychotropic Substances [Shehu 2005:222]. Although money laundering was not explicitly mentioned or defined in the Convention, it was the basis of subsequent regulations to prevent money laundering [Stessens 2000:133].

In 1989, the anti-money laundering rules were institutionalised by a group of 7 industrialized countries (G-7) by creating the Financial Action Task Force (FATF), with a specific mission to combat the money laundering threat. The next year FATF issues the 40 Recommendations as a comprehensive framework for fulfilling its mandate, and later, in 2001, has issued 9 additional Recommendations in order to address the growing concern for terrorism [Bergstrom, Helgesson \& Morth 2011:1044].

The FATF members in accordance with the Recommendations had to adopt laws and regulations by specifying in details how the threat of money laundering in their respective jurisdictions shall be managed. These Recommendations gave rise to the rules-based approach [Ai, Broome and Yan 2010:394], in which the regulatory authorities established the principles and regulations that allow the identification and prevention of actions that involve money laundering.

Every member state was obliged to apply the necessary measures, which were later assessed during a mutual evaluation process. But this approach has not proven its effectiveness, because of being too prescriptive it didn't allow the regulated entities to individualize their own actions according to the existing threats [Ai, Broome and Yan, 2010:394]. Subsequently, this model was found to be expensive to implement and easy to manipulate by using in the money laundering process the amounts even below the regulated threshold in order to avoid sending a suspicious transaction report [Takats 2011:38]. The risk-based approach was introduced later in 2003 by FATF after reviewing the 40 Recommendations [Koker 2009:336]. The document which summed up the efforts of FATF, banking and securities sectors, includes the recognition of the existing risk (risks), by performing a risk assessment and developing the strategies for managing and mitigating the identified risks. 
It follows that AML risk is not clearly defined [Koker 2009:336; Ross, Hannan 2007:110], and the risk-based approach raised more questions than it answered and revealed intrinsic and very real difficulties in managing the relationship between risk and AML [Demetis and Angell 2007:424].

While the adoption of risk-based approach could simply reflect the general move to such broader regulations of financial market, the fact that the risk itself is defined so differently mean that within the AML activities the obliged entities' inability to apply proper risk measurement techniques have led to an inability to distinguish what is really criminal and what is not, which leads to the generation of "a waste of unnecessary information about AML procedures" [Pellegrina and Masciandaro 2009:3]. Clearly, if obliged entities report everything as suspicious, they don't actually report anything [Takats 2011:39].

There is a modest number of researches in the field of efficiency of applying the risk-based model in the area of anti-money laundering, thus there are identified three approaches: the risk-based model as a phenomenon, game theory and agent theory.

Thus, some researchers examined the problems arising from the risk-based approach [Demetis and Angell 2007:424], others followed the application of game theory in identifying the risk of money laundering [Araujo 2010; Arnone, Borlini 2010:68], and a stronger group proposed examining the problem through agent theory [Masciandaro and Filotto 2001:133; Pellegrina and Masciandaro 2009:931; Takats 2011:39]. The problem that underlies the research is the possibility to apply the term of risk as a definition, which implies uncertainty about absolutely concrete phenomena, which can be classified more as crimes due to the certainty arising from the awareness of the final result of the actions carried out by the offenders in the money laundering process. However, in the AML literature and regulatory documents, the terms of risk and uncertainty are sometimes used as interchangeably notions [Guerron-Quintana 2012:10], despite the fact that they are defined differently, the distinction being in the degree of uncertainty of the consequences of a result associated with money laundering.

The discussion at the level of theory regarding the risk-based approach of the moneylaundering process has been transposed into law since 2000 (Fig. 1).
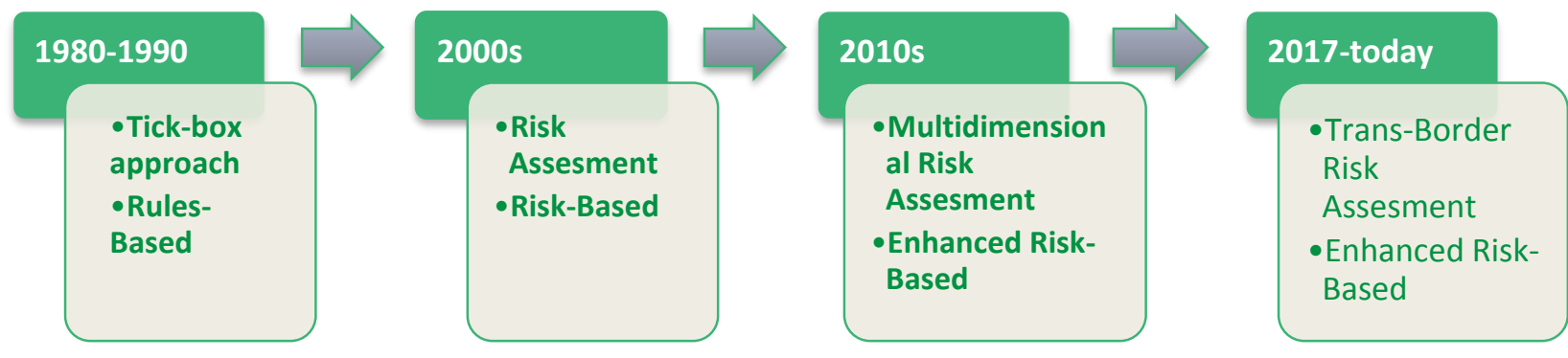

Figure 1. The evolution of the estimation concept of the money laundering phenomenon in the European legislation

Source: Elaborated by the authors based on the Harvey, J. (2008). Just How Effective is Money Laundering Legislation. Security Journal, 21(3), 189-211.

The problem related with the identification of an efficient mechanism for preventing and combating the money laundering phenomenon has always existed and the basis for finding a solution was to identify the best selection criteria for assessing the phenomenon. Thereby, during the evolution of the legislation and practice in the field, the regulation aspect became more robust, by changing from the rule-based principle to the risk-based approach and finally to the enhanced riskbased approach. So, at the international level the Financial Action Task Force (FATF) [https://www.fatf-gafi.org/], which is the standard setter organization for combating money laundering and the financing of terrorism \& proliferation promotes through Recommendation No. 1 [FATF 2012-2019] that:

„Countries should identify, assess, and understand the money laundering and terrorist financing risks for the country, and should take action, including designating an authority or 
mechanism to coordinate actions to assess risks, and apply resources, aimed at ensuring the risks are mitigated effectively. Based on that assessment, countries should apply a risk-based approach (RBA) to ensure that measures to prevent or mitigate money laundering and terrorist financing are commensurate with the risks identified...".

The European Union Supranational Risk Assessments (SNRAs) use an established methodology in order to offer a multilateral analysis of the ML or TF risks associated with the activities and behavior of criminals and offenders. The main task is not to analyze a specific sector as a whole, but to highlight the situations when the products and/or services offered by this sector can be misused for ML or TF scopes. These SNRAs are oriented on vulnerabilities identified at EU level, both in terms of legal framework and in terms of effective application. It does not prejudge the mitigating measures that some Member States are applying or may decide to apply in response to their own national ML/TF risks.

\section{DATA SOURCES AND USED METHODS}

We will analyze European legislation to identify how it treats the money laundering and what forms of risk it assumes would be included in this operation, to demonstrate that in the European Union the ML and FT approach is risk based, but also extended to identify the types of risk per activity.

In order to achieve the stated purpose, a series of scientific research methods were used, among which: the dialectical method, the method of analyzing the literature in the researched field, the comparative method, the induction and the deduction, the scientific abstraction, etc. The use of these methods allowed for a thorough and detailed analysis of European legislation in order to regulate the ML and FT, making some conclusions, but also recommendations on the application but also its improvement. The methodological basis of the article is represented by comparative research in approaching the analysis of the regulatory components.

\section{TRANS-BORDER RISK APPROACH IN EU LEGISLATION}

The 1SNRA [6, 2017] and 2SNRA [7, 2019] state that the actions of ML and TF are complex risks affecting the internal market and relating to trans-border activities are the first two reports performed by the European Union (EU) Commission at a supranational level. The reports are considering the ML and TF risks that the EU could meet and recommend an extensive mechanism to minimize them. Both documents provide the most important risks for the internal market in a large number of sectors and the horizontal vulnerabilities, which can influence these sectors. In this respect, the reports include the mitigating actions that should be implemented at EU and national level in order to minimize these risks, as well as several recommendations for the different institutions implicated in processes of combating ML and TF.

Moreover - the risk-based approach expands with a new concept regarding the coverage area - transborder risk (figure 1). To minimize these trans-border processes, the EU anti-money laundering and combating the financing of terrorism (AML/CFT) structure has introduced unified rules of controls and reporting obligations by the relevant entities and created a vigorous structure for EU Financial Intelligence Units (FIUs) to analyze suspicious transactions and collaborate with each other. Although considerable and durable evolution in this field was obtained, additional improvements and new provisions are necessary in order to strengthen the framework, which will ensure the activities in preventing and fighting ML and TF. The broad view and analysis of money laundering and terrorist financing risks is of paramount importance before any legal proposals or additional regulations will be approved and implemented. In this aspect, the risk assessment is very decisive for the internal market taking into consideration that in their essence the financial flows are integrated and trans-border.

On the other hand, at the European Union level, the Article 6 of the 4AMLD [1,2015] provides specific requirements for the EU Commission to conduct an assessment of the risks of money laundering and terrorist financing affecting the internal market and relating to trans-border activities. As a result, the Commission shall draw up a report identifying, analyzing and evaluating those risks at Union level and shall update its report every two years, or more frequently if appropriate.

The report referred to in above shall cover at least the following:

a) the areas of the internal market that are at greatest risk;

b) the risks associated with each relevant sector;

c) the most widespread means used by criminals to launder illicit proceeds. 
In addition, the Article 7 of the 4AMLD obliges the Member States to take appropriate steps to identify, assess, understand and mitigate the risks of money laundering and terrorist financing affecting the Member State, as well as any data protection concerns in that regard.

Also, it shall keep that risk assessment up to date and shall make use of the findings of the report referred to in Article 6.

After performing their own national risk assessment (NRA), the Member State shall use it to:

a) improve its AML/CFT regime, in particular by identifying any areas where obliged entities are to apply enhanced measures and, where appropriate, specifying the measures to be taken;

b) identify, where appropriate, sectors or areas of lower or greater risk of money laundering and terrorist financing;

c) assist it in the allocation and prioritization of resources to combat money laundering and terrorist financing;

d) ensure that appropriate rules are drawn up for each sector or area, in accordance with the risks of money laundering and terrorist financing;

e) make appropriate information available promptly to obliged entities to facilitate the carrying out of their own money laundering and terrorist financing risk assessments.

Moreover, the Article 8 of the 4AMLD obliges the Member States to ensure that the obliged entities take appropriate steps to identify and assess the risks of money laundering and terrorist financing, by taking into account risk factors including those relating to their customers, countries or geographic areas, products, services, transactions or delivery channels. Those steps shall be proportionate to the nature and size of the obliged entities. In other words, the 4AMLD require the obliged entities under the AML/CFT provisions to assess the money laundering and terrorist financing risk in their own field of activity. As a result, the 4AMLD establishes a three-level system for assessing the risks, threats and vulnerabilities of money laundering and terrorist financing.

Table 1

The EU three-layer system for assessing the money laundering and terrorist financing risk

Layers of EU ML/TF risk assessment Responsible institution

\begin{tabular}{|l|l|l|}
\hline Layer 1 & $\begin{array}{l}\text { At the level of the European Union } \\
\text { (Supranational) }\end{array}$ & EU Commission \\
\hline Layer 2 & $\begin{array}{l}\text { At the level of each EU Member State } \\
\text { (National) }\end{array}$ & The designated authority \\
\hline Layer 3 & $\begin{array}{l}\text { At the level of each obliged entity } \\
\text { (Sectorial) }\end{array}$ & The obliged entities \\
\hline
\end{tabular}

Source: Adapted by the author based on provisions of Art. 6, 7 and 8 of the 4AMLD.

The SNRAs show that all identified sectors are exposed to some additional vulnerabilities:

- infiltration by criminals - criminals can become owners of an obliged entity or find obliged entities willing to assist them in their money laundering activities.

- forgery - modern technology is making it easier to forge documents and all sectors are struggling to put in place robust detection mechanisms;

- insufficient information-sharing between the public and the private sectors -the need for improved mechanisms for feedback from Financial Intelligence Units to obliged entities remains;

- insufficient resources, risk-awareness and know-how to implement anti-money laundering/countering the financing of terrorism rules - while some obliged entities invest in sophisticated compliance tools, many have more limited awareness, tools and capacities in this field; and

- risks related with FinTech - the use of online services is expected to increase further in the digital economy, boosting demand for online identification. The use and reliability of electronic identification is crucial in this respect.

CONCLUSIONS

a) The EU internal market is still sensitive to money laundering and terrorist financing risks, namely because of a wide variety of products and services, different legal and financial systems of 
Member States and new technologies, which can ensure a high level of anonymity. These conditions are creating advantages for perpetrators to launder criminal proceeds.

b) The financial system has a central role in fighting against money laundering. The timely identification of criminal behaviour and money laundering activities followed by the application of provisional measures can help to avoid the abuse of financial services and products.

c) Additional measures are necessary to be applied for strengthening the legal AML/CFT framework of Member States in order to create normative barriers and security layers to be able identify and reject the attempts of criminals to use the reporting entities for criminal purposes.

d) Supervision authorities and reporting entities are dealing with huge workloads on the part related with the application of AML/CFT measures, in some particular cases the capacities of supervision authorities and reporting entities are disproportional with the amounts and volumes of work that they have to perform.

e) Cash and cash like tools are the main ML/TF risk generating instruments.

f) Together with cash and cash like tools, the internet-based businesses such as online casinos, crowd funding platforms, e-money and virtual asset online exchangers are posing substantial levels of ML/TF risks.

\section{RECOMMENDATIONS}

a) In the author's opinion, the most strategic solution that can reduce the exposure of the EU internal market to ML/TF risks is a proper and qualitative transposition of the 4AMLD and 5AMLD into the local legislation of Member States. It is to be mentioned that a strong AML/CFT legal framework should cover a three-level regulation system:

- $1^{\text {st }}$ level composed of Laws (Acts, Bills) approved by central state bodies such as Parliament, Government or Head of State, as the case may be, these regulations should include the general provisions for establishing the AML/CFT regime at a country level.

- $2^{\text {nd }}$ level composed of rules, procedures, instructions, etc. issued by law enforcement agencies and supervision authorities which regulate their competences related with specific sectors and/or reporting entities, functions and attributions, rights and obligations according to the limits set up by the 1 level.

- $3^{\text {rd }}$ level composed of internal policies and programs of reporting entities and other thirdparty institutions which included specific provisions associated with their own field of activity and with the business they are carrying out.

b) Member States should ensure that the virtual assets (crypto assets) and natural/legal persons that are carrying out business activities with virtual assets are duly regulated in accordance with the 5AMLD. The most problematic part is to identify the authority, which will play the role of the supervisor, it is necessary to designate the most appropriate institution, so as to, guarantee that it has enough human, financial and technical resources and institutional capacities to regulate and supervise the activity of virtual asset businesses. In this regard, the Member States can use not only the 5AMLD, but also the provisions of FATF Recommendation No. 15 (New technologies) in order to identify the activities, which can be qualified as virtual asset businesses. It is to be mentioned, that a very important aspect is to avoid as much as possible the anonymity in transactions with virtual assets. Thus, the Member States shall make sure that the virtual asset businesses operating on their territories are applying proper Customer Due Diligence measures.

c) The financial supervision authorities should have sufficient resources to fully carry out their functions in relation with obliged entities and work amount, which results from their attributions. The human resources must be adjusted i.e. it is necessary to have a sufficient number of staff incharged with AML obligation. In addition, the education and training of staff should be a continuous priority in order to ensure the highest level of staff qualification. The AML/CFT divisions should be supplied with special equipment and software which will offer the possibility to detect in due time the potential illegal activities, as well as to generate certain operational or strategic reports regarding the trends of using the financial services or products. A very important aspect is the proper remuneration of AML/CFT personnel, this principle is necessary to be respected in order to avoid the unhealthy flow of staff and thus to preserve the institutional memory and experience gained during long periods of time. The supervision authorities should guarantee that they have the possibility to 
freeze or block the suspicious transactions and operations, even if the reporting entity didn't apply the provisional measures for some reasons. The supervision authorities should reserve the right to apply the provisional measures on their own initiative in a rapid and efficient manner, until the transactions or operations are properly verified.

d) In order to ensure a good application of AML rules it is necessary to pay a special attention to persons who are qualified as founders or shareholders of reporting entities, as well as to persons which are holding senior management positions. The supervision authorities should apply enough fit and proper procedures, especially in relation with big obliged entities. The quality of persons, which are holding or managing the obliged entity can be essential when it comes to minimizing the ML/TF risks. In this regard, the supervision and regulation authorities should make sure that the obliged entity's structure of ownership and control is transparent and that the persons, which are exercising the control through different means have impeccable reputation.

e) The personnel of supervision authorities and reporting entities who are exercising functions in AML/CFT divisions should have legal guaranties and protection measures in order to avoid inappropriate influences because of the specificity of activity that they are performing, these measures should be organized in a manner that will minimize any pressing or improper influence over the employees.

f) An increased attention should be paid on the proper and correct application of due diligence measures in regard not only to new, but also to existing customers. The most common constantly repeated mistake is the fact that the employees of obliged entities are not collecting enough information and documents and are ignoring the necessity to verify the obtained data by using other relevant and trustworthy sources of information, which is paramount for preventing any abuse of criminals. The training of front office personnel is very important for ensuring that the reporting entities have sufficient information, so as to, understand the risk profile of customers. The front officers are those who are interacting directly with clients and they are the first defence line and the quality of their training and education is directly proportional with the integrity of a reporting entity.

g) From the AML perspective the exchange of information between the relevant institutions plays a central role for the protection of a certain jurisdiction from undue influence of criminal elements. The cooperation among authorities at the national level and at the level of Member States should be organized both vertically and horizontally between FIU, supervision authorities, law enforcement agencies and obliged entities. The participants of the AML/CFT chain should be encouraged to exchange information on a regular and spontaneous basis and should contain at least the typologies and ML trends, the list of proceeds generating criminal offences, the list of jurisdictions, products, services and customers profiles, which can posse potential ML/TF risks, as well as the black list of natural and legal persons which should be rejected because of high ML/TF threats. The exchange of information should be organized, so as to, ensure a high level of confidentiality and protection of personal data.

h) It is a good practice to arrange the gradually decrease of cash in the circulation, as well as to shrink the dissemination and use of high denomination banknotes, which are the favourite of money launderers and criminal organizations. Cash is the main instrument, which has the highest level of money laundering and terrorism financing risk because it offers the possibility to guarantee the anonymity, as well as to avoid to a certain degree the recording and tracing of transactions and operations, in this regard cash can be freely transported and exchanged. The Member States, which are traditionally oriented on a cash-based structure of economy are facing higher ML/TF risk. With little effort, the cash obtained through proceeds generating offences can be easily introduced in the circulation of the legal economy. On the other hand, the economies which are primarily using other payment instruments as credit/debit cards or wire transfers have lower ML/TF risks, this fact is possible due to different levels of security, such as registration of every transaction or operation and other relevant information, which offers the possibility to identify and prevent in a timely manner the suspicious and/or criminal activities. 


\section{BIBLIOGRAPHY}

1. Directive (EU) of the European Parliament and of the Council on the prevention of the use of the financial system for the purposes of money laundering or terrorist financing, amending Regulation (EU) no. 648/2012 of the European Parliament and of the Council, and repealing Directive 2005/60/EC of the European Parliament and of the Council and Commission Directive 2006/70/EC (Text with EEA relevance): 2015/849 of 20 may 2015 [citat 11 decembrie 2019]. Disponibil: https://op.europa.eu/en/publication-detail/-/publication/0bff31ef-0b49-11e58817-01aa75ed71a1/language-en

2. Directive jof the European Parliament and of the Council on the prevention of the use of the financial system for the purpose of money laundering and terrorist financing: 2005/60 of 26.10.2005 [citat 11 decembrie 2019]. Disponibil: https://eur-lex.europa.eu/legalcontent/EN/TXT/?uri=CELEX\%3A32005L0060

3. FINANCIAL ACTION TASK FORCE. International Standards on Combating Money Laundering and the Financing of Terrorism \& Proliferation 2012-2019. Paris, 2019, june [citat 23 decembrie 2019]. Disponibil: https://www.fatf-gafi.org/media/fatf/documents/ recommendations/pdfs/FATF\%20Recommendations\%202012.pdf

4. Final Act of the United Nations Conference for the Adoption of a Convention Against Illicit Traffic in Narcotic Drugs and Psychotropic Substances. Convention Against Illicit Traffic in Narcotic Drugs and Psychotropic Substances. 1988 [citat 11 decembrie 2019]. Disponibil: https://www.fatf-gafi.org/

5. Methodology for assessing money laundering and terrorist financing risks affecting the internal market and related to cross-border activities. 2015, 4 november. 56 p. [citat 11 decembrie 2019]. Disponibil: https://www.google.com/url?sa=t\&source=web\&rct=j\&url= http://fatfplatform.org/wp-content/uploads/2016/03/04112015-Methodology-SNRA-Cleanv1.1.pdf\&ved=2ahUKEwiv5ZDgjIHpAhXLsKQKHdoHBToQFjADegQIAhAB\&usg=AOvVaw1AlgbO q6_s5s7PycnzccPR\&cshid=1587732721619

6. Report from the Commission to the European Parliament and the Council on the assessment of the risk of money laundering and terrorist financing affecting the internal market and relating to cross-border activities. 2017 [citat 11 decembrie 2019]. Disponibil: https://eurlex.europa.eu/legal-content/en/TXT/?uri=CELEX\%3A52017DC0340

7. Report from the Commission to the European Parliament and the Council on the assessment of the risk of money laundering and terrorist financing affecting the internal market and relating to cross-border activities. 2019, july [citat 21 decembrie 2019]. Disponibil: https://op.europa.eu/en/publication-detail/-/publication/0b2ecb04-aef4-11e9-9d0101aa75ed71a1/language-en

8. The Commission of the European Communities Secretariat-General. In: Official Journal of the European Communities. 1986, vol 29, no C 283/79-81, p. 77. ISSN 0378-6986.

9. The European Parlament. Resolution on the drug problem. In: Official Journal of the European Communities. 1986, vol 29, no C 283/79-81. ISSN 0378-6986.

10. BRÒOME, J., AI, L. Yan, H. Carrying out a risk-based approach to AML in China: partial or full implementation? In: Journal of Money Laundering Control. 2010, vol. 13, no. 4, pp. 394-404. ISSN 1368-5201.

11. ARAUJO, R.A. Assessing the efficiency of the anti-money laundering regulation: an incentivebased approach. In: Journal of Money Laundering Control. 2008, vol. 11, no. 1, pp. 67-75. ISSN 1368-5201.

12. BERSTROM, M., HELGESSON, K.S., MORTH, U. A New Role for For Profit Actors? The Case of Anti Money Laundering and Risk Management. In: Journal of Common Market Studies. 2011, vol. 49, no. 5, pp. 1043-1064. ISSN 1468-5965.

13. BROEK, van den M. The EU's preventive AML/CFT policy: asymmetrical harmonisation. In: Journal of Money Laundering Control. 2011, vol 14, no. 2, pp. 170-182. ISSN 1368-5201.

14. DEMETIS, D.S., ANGELL, I.O. The risk-based approach to AML: representation, paradox, and the 3rd directive. In: Journal of Money Laundering Control. 2007, vol. 10, no. 4, pp. 412-428. ISSN 1368-5201. 
15. GUERRON-QUINTANA, Pablo. Risk and uncertainty. In: Business Review. Federal Reserve Bank of Philadelphia. 2012, issue Q1, pp. 9-18. ISSN 0007-7011.

16. HARVEY, J. Just How Effective is Money Laundering Legislation? In: Security Journal. 2008, vol. 21, no. 3, pp. 189-211. ISSN 1743-4645.

17. DE KOKER, L. Identifying and managing low money laundering risk. In: Journal of Financial Crime. 2009, vol. 16, no. 4, pp. 334-352. ISSN 1359-0790.

18. MASCIANDARO, D., FILOTTO, U. Money laundering regulation and bank compliance costs: What do your customers know? Economics and the Italian experience. In: Journal of Money Laundering Control. 2001, vol. 5, no. 2, pp. 133-145. ISSN 1368-5201.

19. MCCARTHY, K.J., SANTEN, van P., FIEDLER, I. Modeling the money launderer: Microtheoretical arguments on anti-money laundering policy. In: International Review of Law and Economics. 2015, vol. 43, pp. 148-155 [citat 21 noiembrie 2019]. Disponibil: https://doi.org/10.1016/j.irle.2014.04.006

20. PELLEGRINA, L.D., MASCIANDARO, D. The risk-based approach in the New European antimoney laundering legislation: a law and economics view. In: Review of Law and Economics. 2009, vol. 5, no. 2, pp. 931-952. ISSN 1555-5879.

21. ROSS, S., HANNAN, M. Money laundering regulation and risk-based decision making. In: Journal of Money Laundering Control. 2007, vol. 10, no. 1, pp. 106-115. ISSN 1368-5201.

22. SATHYE, M., ISLAM, J. Adopting a risk-based approach to AMLCTF compliance: the Australian case. In: Journal of Financial Crime. 2011, vol. 18, no. 2, pp. 169-182. ISSN 1350-0790.

23. SCHNEIDER, F., WINDISCHBAUER, U. Money laundering: some facts. In: European Journal of Law and Economics. 2008, vol. 26, no. 3, pp. 387-404. ISSN 0929-1261.

24. SHEHU, A.Y. International Initiatives against Corruption and Money Laundering: an Overview. In: Journal of Financial Crime. 2005, vol. 12, no. 3, pp. 221-245. ISSN 1350-0790.

25. SIMONOVA, A. The risk-based approach to anti-money laundering: problems and solutions. In: Journal of Money Laundering Control. 2011, vol. 14, no. 4, pp. 346-358. ISSN 1368-5201.

26. STESSENS, G. Money Laundering: A New International Law Enforcement Model. Cambridge University Press. Cambridge. 2000 [citat 21 noiembrie 2019]. Disponibil: http://dx.doi.org/10.1017/CB09780511494567

27. TAKATS, E.A Theory of "Crying Wolf 1 : The Economics of Money Laundering Enforcement. In: Journal of Law, Economics \& Organization. 2011, vol. 27, no. 1, pp. 32-78. ISSN 1465-7341.

\section{ARTICLE HISTORY}

Received 09 December 2019

Accepted 05 May 2020 